\title{
South Brazilian farmers' perceptions concerning sheep tail docking
}

\author{
Fabiana de Orte Stamm ${ }^{1}$ (iD) Marcelo Beltrão Molento ${ }^{2,3}$ iD Carla Forte Maiolino Molento ${ }^{1^{*}}$ (iD) \\ ${ }^{1}$ Laboratório de Bem-Estar Animal (LABEA), Departamento de Zootecnia, Universidade Federal do Paraná (UFPR), 80035-050, Curitiba, PR, \\ Brasil. E-mail: carlamolento@ufpr.br. "Corresponding author. \\ ${ }^{2}$ Laboratório de Doenças Parasitárias, Departamento de Medicina Veterinária, Universidade Federal do Paraná (UFPR), Curitiba, PR, Brasil. \\ ${ }^{3}$ Instituto Nacional de Ciência e Tecnologia - Informação Pecuária, Belo Horizonte, MG, Brasil.
}

ABSTRACT: The objective of this study was to better understand farmers 'perceptions regarding sheep welfare and procedures concerning the tail docking of sheep in the state of Parana, Southern Brazil. The study was carried out via telephone interviews or personally with 146 sheep farmers. Twenty-eight farmers (19.2\%) did not tail dock; the main reasons given were because they raised short-hair sheep breeds. One hundred and eighteen farmers docked their sheep tails (80.8\%). The main reasons given were hygiene (61.0\%), facilitated mating (42.4\%), breed standards (29.7\%), and esthetics (26.3\%). Rubber ring was the main method used for tail docking. Although farmers in Parana recognized that sheep are sentient animals and that tail docking causes pain, anesthesia was used by only six (5.1\%) farmers during the procedure of tail docking. Our results showed that farmers'opinions on sheep tail docking are divergent. Farmers who perform tail docking must be encouraged to use anesthesia and analgesia, and to ponder on the real need for the practice. This statement seems especially relevant considering the fact that some farmers reported the viability of maintaining wool sheep with undocked tails and that they recognized the suffering involved in this procedure.

Key words: animal welfare, lamb, Ovis aries, pain, rubber ring.

Percepção dos ovinocultores do sul do Brasil com relação à caudectomia em ovinos

RESUMO: O objetivo deste trabalho foi compreender melhor a percepção de ovinocultores em relação ao bem-estar de ovinos e aos procedimentos envolvendo a caudectomia desses animais no Paraná, sul do Brasil. O estudo foi realizado por meio de entrevistas telefônicas ou pessoalmente com 146 ovinocultores. Vinte e oito ovinocultores $(19,2 \%)$ não realizavam caudectomia; a principal razão citada foi porque os produtores criavam ovelhas deslanadas (pelo curto). Cento e dezoito ovinocultores realizavam a caudectomia (80,8\%) e as principais razões citadas foram: higiene (61,0\%), monta facilitada (42,4\%), padrão racial (29,7\%) e estética (26,3\%). O principal método utilizado para realizar a caudectomia foi o anel de borracha. Apesar dos ovinocultores no Paraná reconhecerem que ovinos são animais sencientes e que a caudectomia causa dor, somente seis (5,1\%) aplicavam anestesia durante o procedimento. Nossos resultados demonstram que a opinião dos ovinocultores com relação à caudectomia é divergente. Ovinocultores que realizam a caudectomia devem ser encorajados a usar anestesia e analgesia, além de ponderar a real necessidade para essa prática. Essa afirmação se mostra relevante ao considerar o fato de que alguns produtores relataram a viabilidade de manter ovinos lanados com cauda inteira e o reconhecimento por parte deles do sofrimento causado aos animais durante a remoção da cauda.

Palavras-chave: bem-estar animal, cordeiro, Ovis aries, dor, anel de borracha.

\section{INTRODUCTION}

Even with the growing consumer concern about the welfare of animals (MAYFIELD et al., 2007), there are still some procedures that cause pain and suffering to farm animals. Cattle disbudding and dehorning(KLING-EVEILLARD etal., 2015), extrateat removal, castration (HÖTZEL et al., 2014), and sheep tail docking (SUTHERLAND \& TUCKER, 2011) are procedures performed to ruminants with little or no use of pain control methods.

Tail docking is a common procedure carried out in sheep farms in countries as United
Kingdom, Australia, New Zealand, Canada, and Brazil(KENT etal., 2000; MORRIS, 2000; SEBRAE, 2009; COCKRAM et al., 2012). There are different methods of tail docking, including hot iron, rubber ring, rubber ring combined with clamp, crush and cut, and surgery (NATIONAL FARM ANIMAL CARE COUNCIL, 2013).

According to scientific literature, there are physiological and behavioral evidence suggesting that tail docking methods are acutely painful to sheep (NATIONAL FARM ANIMAL CARE COUNCIL, 2013; SUTHERLAND \& TUCKER, 2011; COCKRAM et al., 2012). Lambs who had their 
tails docked without local anesthetic, for example, had increased plasma cortisol and showed abnormal postures (KENT et al., 2000, 2001). It is clear that tail docking negatively impacts sheep welfare, since this procedure causes pain and suffering, manifested by irregular jumping and pain-compatible vocalization.

In Brazil, tail docking is recommended and considered common practice in recommendations for sheep production (SEBRAE, 2009; DEMINICIS et al., 2013). According to the Article 5, paragraph 2 of the resolution $\mathrm{n}^{\circ} 877$ from February 152008 , from the Brazilian Federal Council of Veterinary Medicine, tail docking is forbidden in sheep (CFMV, 2008). This prohibition was later modified by Annex 2, included on Article 6 from the Resolution $n^{\circ} 928$ of 2009. Since then, tail docking is allowed for wool sheep breeds, previously submitted to anesthesia and analgesia (CFMV, 2009). However, the modification of CFMV resolution in 2009 allowing for the tail docking of wool breeds is controversial, since there is no consensus of its benefits. According to a study in São Paulo, Brazil, tail amputation practiced by breeders as a hygienic measure did not prevent myiasis by the larvae of Cochliomyia hominivorax. Conversely, the lesion that occurred as a result of the procedure seemed to allow for the establishment of screw-worm infestation since animals, mainly Suffolk and Corriedale sheep, who were tail-docked presented twice the infestation rate, as compared to those who had intact tails (MADEIRA et al., 1998). In a review of three studies comparing the effect of tail docking with undocked controls, only one study reported a clear reduction on fly strike in docked sheep (SUTHERLAND \& TUCKER, 2011).

Knowledge of farmers' perceptions towards painful practices performed in farm animals is relevant to define arguments that can be useful to help farmers in improving or replacing some practices (KLING-EVEILLARD et al., 2015). Therefore, it is important to understand the reasons given for tail docking, to refute them in cases where these suppositions are untrue or to account for reasons which are backed by science, and to value the opinions of farmers who do not tail dock their sheep. Thus, the objective of this study was to better understand farmers' perceptions regarding sheep welfare and procedures concerning the tail docking of sheep in the state of Parana, Southern Brazil.

\section{MATERIALS AND METHODS}

The study was carried out via telephone $(n=188)$ or personal $(n=12)$ interviews with farmers, from October 2014 to July 2015, in the state of Parana in Brazil (Figure 1). The interviews constituted a sample with a margin of error of $7 \%$ and $95 \%$ confidence interval. The farms accounted to a total of 17,434 animals (IBGE, 2006). Farmers were invited

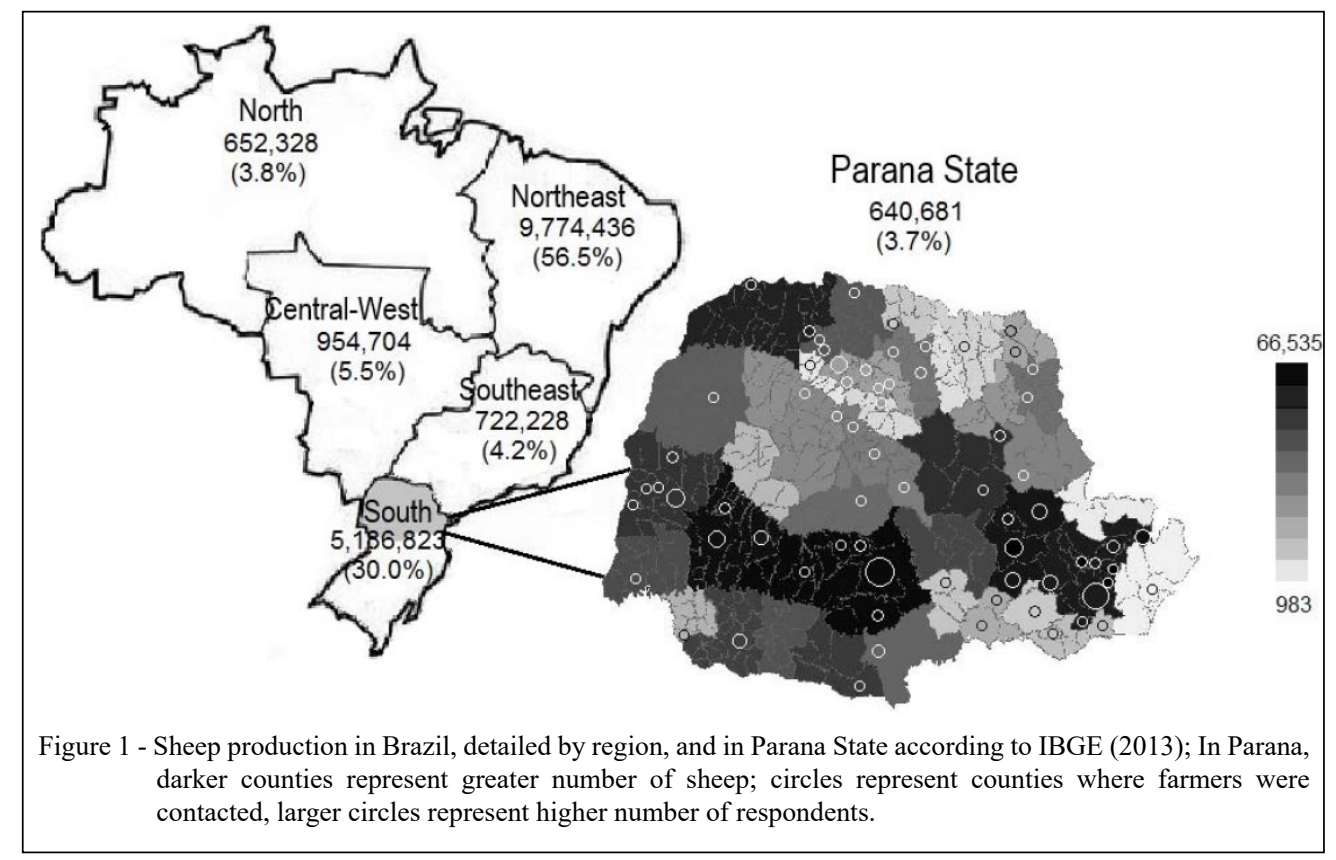

Ciência Rural, v.49, n.4, 2019. 
to participate via contact details provided by sheep associations and cooperatives from Parana, and by other farmers. All contacted farmers that agreed to be interviewed were included in the research.

The semi-structured (ROBSON, 2002) questionnaire consisted of seventeen questions: two questions about demographic data, three questions about production characteristics, seven on the tail docking procedure, three on farmers' perceptions of sentience and pain during tail docking in sheep, and two on general sheep farm management. There were predetermined questions, but questions differed depending on the answer for the initial question: Do you perform tail docking on your sheep? Answers were transcribed to a spreadsheet during interview.

Data were analysed using Minitab Statistical Software version 17. Questions about farmers' perceptions were analysed using Chi-Square Test for Association, to compare differences in opinion between men and women. Reported frequency of infestation by ovine cutaneous myiasis was analysed using the Wilcoxon rank sum test. As an addition, some relevant beliefs were quoted as examples.

\section{RESULTS AND DISCUSSION}

Of all the farmers contacted, 52 no longer maintained sheep and two farmers quit the interview before answering all questions. Of the remaining 146 respondents, $123(84.2 \%)$ were men. The main breeds of sheep were Texel (46.6\%), Santa Inês (35.6\%), Dorper $(31.5 \%)$, and Ile de France $(32.2 \%)$. From those, 76 farmers (52.1\%) raised more than one breed.

Twenty-eight $(19.2 \%)$ farmers did not dock tails. Eleven (39.3\%) farmers gave more than one reason not to tail dock (Figure 2A). Considering eight farmers who did not dock wool-breed sheep, five used to dock and have changed their perceptions. One farmer said the following: "Tail docking requires a lot of work, and it is unnecessary. For this reason, I no longer dock and I have not seen any difference since then in animals' management when comparing sheep with or without the tail". Opinions from such farmers seem important as they have experienced both situations and are thus in a privileged position to report on the tail docking of wool sheep.

The main reason given not to dock sheep tails was because respondents raised haired sheep, which do not accumulate as much dag, urine, and faeces on the breech region, compared to wool sheep. Additionally, tail docking is recommended by guidebooks of sheep production only for wool breeds (SEBRAE, 2009). Other reasons not to dock include farmers' belief that the tail is a natural part of the animal and it is important to swat flies. As mentioned by SUTHERLAND \& TUCKER (2011), negative side effects of tail docking include the inability to use the tail for other purposes, such as fly removal

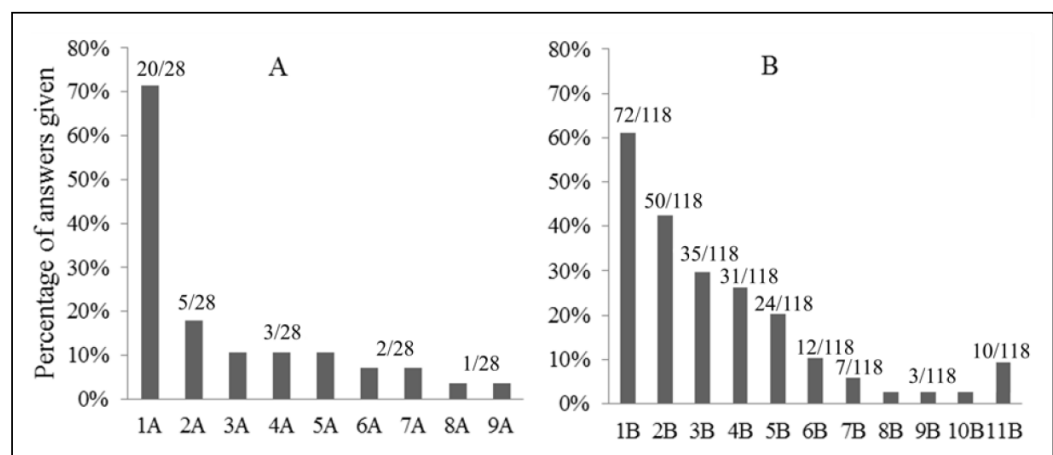

Figure 2 - Reasons given not to tail dock (A) and to tail dock (B) sheep according to 146 farmers from Parana State, Brazil. Main reasons not to tail dock: 1A. raised haired breed; 2A. unnecessary procedure; 3A. tail is important to swat flies; 4A. tail docking requires more labor; $5 \mathrm{~A}$. tail is a natural part of the sheep; 6A. avoid sheep pain ; 7A. myiasis occurrence on the tail docking procedure lesion; 8A. cause stress in sheep; 9A. tail docking is going to be a forbidden procedure. Main reasons given for tail docking sheep: 1B. hygiene; 2B. facilitate mating; 3B. breed standard; 4B. esthetics; 5B. hygiene only during parturition; 6B. only for cultural reasons; 7B. avoidance of dirt in ram's penis during copulation; 8B. differentiation between rams and ewes; 9B. avoid myiasis and other ectoparasites; 10B. facilitate parturition; 11B. other reasons. 
or manifest external reactions (e.g. to communicate stress or positive feelings).

One hundred and eighteen farmers docked tails (80.8\%) and 76 (64.4\%) farmers gave more than one reason for tail docking (Figure 2B). The main reason was hygiene and the second most common reason given was that it facilitates mating, which was also mentioned in guidelines for sheep production (DEMINICIS et al., 2013). The third and fourth most common reasons for tail docking were breed standard and esthetics, evidencing how local culture may negatively influence animal welfare. Twelve (10.2\%) farmers docked only for cultural reasons, including breed standard, esthetics, and/ or tradition. One producer mentioned: I think tail docking is unnecessary and I do not like applying rubber ring but it is standard for the breed, and if I do not dock, I will not find buyers for my animals. Similarly, other studies have reported that sheep and dairy farmers carried out some management practices as part of well establish traditions, rather than following technical knowledge, and do not recognize the need to justify these practices (MOLONY \& KENT, 2007; HÖTZEL et al., 2014). Because some breed standards require that animals be docked, it is clear that these standards are a hindrance to improve sheep welfare. So we believe that a substantial change regarding breed standards is needed in order to reduce unnecessary pain and discomfort to these animals.

Docking was done by $68.9 \%$ of breeders who had Dorper and by $30.8 \%$ of farmers who had Santa Inês (native short-haired breed); although this procedure is only allowed on wool sheep breeds. Thus, in opposition to the CFMV resolutions (CFMV, 2008; CFMV, 2009), tail docking is still performed in haired breeds in the country. Other reasons mentioned for tail docking were: facilitation of suckling by lambs (1.7\%), tradition $(1.7 \%)$, increased fertility in ewes $(1.7 \%)$, better acceptance from buyers $(1.7 \%)$, identification between purebred and crossbred $(0.8 \%)$, easiness of health management $(0.8 \%)$, and following other farmers' recommendations $(0.8 \%)$. As observed by TE VELDE et al. (2002) farmers' perceptions seem to be based on collective tradition and shared convictions, as mentioned by a farmer from our study: "I don't know why do we have to tail dock, but other farmers do it, so it must be an important practice".

Regarding tail docking techniques, most farmers docked tails using rubber ring (82.2\%), followed by rubber ring with surgical removing of tails some hours after $(5.1 \%)$, surgical removing of tails with scalpel $(5.1 \%)$, electrical pliers (3.4\%), hot iron $(2.5 \%)$, and rubber ring with cauterization some hours after (1.7\%). Rubber rings are an easy, low-cost and effective method of tail docking young lambs (KENT et al., 2001), and that was probably a major reason why it is the main method used for tail docking in Parana. Regarding pain levels, a study in which rubber rings were used for both castration and tail docking, the incidence of abnormal behavior and peak cortisol responses were higher than when used hot iron or burdizzo (KENT et al., 2001). Therefore, the use of rubber ring seems to be problematic in relation to animal welfare, especially considering the rare use of pain control medication.

Only six $(5.1 \%)$ farmers used anesthesia during the procedure of tail docking. Ninety-two $(78.0 \%)$ farmers performed injury management of animals after tail docking, including use of iodine, fly repellent sprays, and ointment. The low use of anesthesia, which was also observed for dairy calves (HÖTZEL et al., 2014) and cattle farms (KLINGEVEILLARD et al., 2015), showed that this is an urgent issue, since the use of anesthesia and analgesia is an absolute requirement when painful procedures are performed to animals (CFMV, 2009).

There was no difference in the frequency of infestation by myiasis or fly strike reported by farmers between sheep with or without tail $(\mathrm{P}=0.540)$ (Table 1). Two farmers $(1.4 \%)$ answered that fly strike occurred only because of the injury caused by the procedure of tail docking. As indicated in another study, lesions related to tail docking seem to benefit the establishment of screw-worms (MADEIRA et al., 1998). Two farmers said that tetanus is a common problem in sheep docked with rubber ring, and stated: "I think that animal welfare is hypocrisy. I do not dock only because I have lost several lambs because of tetanus caused by rubber rings".

Although the vast majority of farmers in Parana routinely use the procedure of tail docking, our results revealed that farmers' opinions and views on sheep tail docking are divergent. We believe that farmers in other and more traditional areas may have different opinions, such as in Rio Grande do Sul, South of Brazil, where sheep market is more pronounced for both meat and wool. In opposition, in the Northeast of Brazil there are mostly short-haired breeds, with no indication or cultural belief leading to tail docking.

In our study, of the 14 farmers who keep both docked and undocked Ile de France, Texel and crossbred ewes, five farmers said that there is no difference in the handling of the animals and nine farmers said that sheep with long tail require the most 
Table 1 - Influence of sheep tail docking on the frequency of infestation by fly strike, as reported by 146 farmers interviewed from October 2014 to July 2015 in Parana State, Brazil.

\begin{tabular}{|c|c|c|c|c|c|c|}
\hline \multirow[t]{2}{*}{ Tail docked } & \multicolumn{4}{|c|}{ - } & \multirow[t]{2}{*}{$\mathrm{N}$} & \multirow[t]{2}{*}{ P-value } \\
\hline & Frequently & Occasionally & Rarely & Never & & \\
\hline Yes & $13(11.0 \%)$ & $34(28.8 \%)$ & $39(33.1 \%)$ & $32(27.1 \%)$ & 118 & 0.5400 \\
\hline No & $2(7.1 \%)$ & $7(25.0 \%)$ & $11(39.3 \%)$ & $8(28.6 \%)$ & 28 & \\
\hline
\end{tabular}

$\mathrm{N}=$ Number of respondents

labor, as sustained here: "Sheep with tail have more urine and faeces accumulated; we need to cut dirt off with scissors and when these animals have myiasis on the breech, the medicine is removed by the tail". Conversely, three farmers who did not dock said that the procedure of tail docking requires the most labor and they believe that this practice is unnecessary. Three farmers reported that tails are important to the animals to avoid fly strike. An example of what they said: "If it is the nature of the animal to have a tail, why do people remove it? The tail is there for a reason. Swatting flies, for example".

There was no difference in the perception of pain $(\mathrm{P}=0.567)$ and discomfort $(\mathrm{P}=0.183)$ during tail docking in sheep when we compared responses from men and women (Table 2). When asked if sheep have the capacity to suffer and experience fear and pain, all 146 farmers answered positively, believing that sheep are sentient beings. But although $80.8 \%$ of respondents believed that tail docking is painful, farmers deal with ambivalence regarding treatment of farm animals. Farmers may use strategies to solve personal uncomfortable feelings such as not being attached to their meat-producing animals that are sent to abattoir, for example (TE VELDE et al., 2002).
Considering tail docking, farmers may use these strategies, as it may decreases any discomfort they may feel, and continue to perform painful procedures. As mentioned before, results showed that farmers need to be informed and trained about the relevance of animal welfare, especially in relation to pain and discomfort, avoiding the suffering of farm animals. Field veterinarians should also be aware of their Federal legislation and their obligation to inform their local counterparts.

\section{CONCLUSION}

Although the majority of farmers dock their sheep tail without pain control, for the main reason of hygiene, our results suggested that farmers in Parana recognize that sheep are sentient animals and that tail docking causes pain. Farmers who perform tail docking must be encouraged to use anesthesia and analgesia, and to ponder on the real need for the practice. This statement seems especially relevant considering the fact that some farmers reported the viability of maintaining wool sheep with undocked tails and that they recognized the suffering involved in this procedure.

Table 2- Perception of pain and discomfort in sheep during tail docking as reported by 146 farmers interviewed from October 2014 to July 2015 in Parana State, Brazil, comparing man and women answers.

\begin{tabular}{|c|c|c|c|c|c|c|}
\hline \multirow[t]{2}{*}{ Tail docking consequence, number of respondents } & \multicolumn{5}{|c|}{ 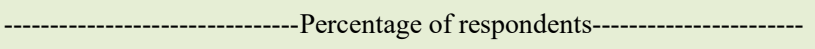 } & \multirow[t]{2}{*}{ P-value } \\
\hline & Yes & No & Some animals & Maybe & Did not know & \\
\hline Pain, 146 & 80.8 & 17.1 & 0.7 & 0.7 & 0.7 & 0.567 \\
\hline Men, 123 & 81.3 & 16.3 & 0.8 & 0.8 & 0.8 & \\
\hline Women, 23 & 78.3 & 21.7 & 0.0 & 0.0 & 0.0 & \\
\hline Discomfort, 146 & 88.4 & 9.6 & 0.0 & 2.0 & 0.0 & 0.183 \\
\hline Men, 123 & 90.2 & 8.1 & 0.0 & 1.6 & 0.0 & \\
\hline Women, 23 & 78.3 & 17.4 & 0.0 & 4.3 & 0.0 & \\
\hline
\end{tabular}




\section{ACKNOWLEDGEMENTS}

The authors are grateful to the sheep cooperatives in Parana State for putting us in contact with farmers; to Ms. Janayna Navroski who interviewed farmers personally, to all the farmers for their participation; and to Mr. Jeremy Klemin for helping us with English review. This study was financed in part by the Coordenação de Aperfeiçoamento de Pessoal de Nível Superior - Brasil (CAPES) - Finance Code 001, as a M.Sc. scholarship to F.O. Stamm.

\section{BIOETHICS AND BIOSSECURITY COMMITTEE APPROVAL}

This study was approved by the Ethics Committee on Research on Humans of the Federal University of Parana (UFPR), protocol number 34820114.0.0000.0102.

\section{DECLARATION OF CONFLICT OF INTERESTS}

The authors declare no conflict of interest. The founding sponsors had no role in the design of the study; in the collection, analyses, or interpretation of data; in the writing of the manuscript, and in the decision to publish the results.

\section{AUTHORS' CONTRIBUTIONS}

All authors contributed equally for the conception and writing of the manuscript. All authors critically revised the manuscript and approved of the final version.

\section{REFERENCES}

CFMV. Conselho Federal de Medicina Veterinária. Resolução n.877, de 15 de fevereiro de 2008. Available from: <portal.cfmv. gov.br/lei/download-arquivo/id/508>. Accessed: Jun. 04, 2018.

CFMV. Conselho Federal de Medicina Veterinária. Resolução n.928, de 13 de dezembro de 2009. Available from: <portal.cfmv. gov.br/lei/download-arquivo/id/508>. Accessed: Jun. 04, 2018.

COCKRAM, M.S. et al. Code of practice for the care $\&$ handling of sheep: review of scientific research on priority issues. Guelph:Canadian Sheep Federation, 2012. 134p.

DEMINICIS, B.B. et al. Considerações sobre ovinocaprinocultura: Dúvidas do Criador Capixaba. Alegre: CAUFES, 2013. 15p.

HÖTZEL, M.J. et al. A survey of management practices that influence performance and welfare of dairy calves reared in Southern Brazil. Plos One, v.9, n.12, p.1-17, 2014. Available from: $<$ http://journals.plos.org/ plosone/article?id=10.1371/journal.pone.0114995>. Accessed: Jun. 15, 2018. doi: 10.1371/journal.pone.0114995.

IBGE. Censo agropecuário 2006. Available from: $<$ https://www. ibge.gov.br/estatisticas-novoportal/economicas/agricultura-epecuaria/9827-censo-agropecuario. $h \mathrm{tml}$ ?edicao $=9829 \mathrm{\& t}=$ publicac oes>. Accessed: Apr. 20, 2018.

IBGE. Banco de dados agregados. 2013. Available from: $<$ http:// www.sidra.ibge.gov.br/bda/tabela/listabl.asp?c=3939\&z=p\&o=27>. Accessed: Apr. 20, 2018.
KENT, J.E. et al. Effects of acute pain reduction methods on the chronic inflammatory lesions and behaviour of lambs castrated and tail docked with rubber rings at less than two days of age. The Veterinary Journal, v.160, p.33-41, 2000. Available from: <https://www.sciencedirect. com/science/article/pii/S1090023300904659?via\%3Dihub>. Accessed: Jun. 20, 2018. doi: 10.1053/tvj1.2000.0465.

KENT, J.E. et al. The effect of different bloodless castrators and different tail docking methods on the responses of lambs to the combined Burdizzo rubber ring method of castration. The Veterinary Journal, v.162, n.3, p.250-254, 2001. Available from: <https:// www.sciencedirect.com/science/article/pii/S1090023301905982>. Accessed: Jun. 20, 2018. doi: 10.1053/tvj1.2001.0598.

KLING-EVEILLARD, F. et al. Attitudes of farmers towards cattle dehorning. Livestock Science, p.1-10, 2015. Available from: $<$ https:// www.sciencedirect.com/science/article/pii/S1871141315002413>. Accessed: Jun. 04, 2018. doi: 10.1016/j.livsci.2015.05.012.

MADEIRA, N.G. et al. Effect of management practices on screwworm among sheep in São Paulo State, Brazil. Tropical animal health and production, v.30, n.3, p.149-157, 1998. Available from: $<$ https://link.springer.com/article/10.1023/A:1005055518916>. Accessed: Jun. 04, 2018.

MAYFIELD, L.E. et al. Consumption of welfare-friendly food products in Great Britain, Italy and Sweden, and how it may be influenced by consumer attitudes to, and behaviour towards, animal welfare attributes. International Journal of Sociology of Food and Agriculture, v.15, n.3, 2007. Available from: <http://www.ijsaf.org/ contents/15-3/mayfield/index.html>. Accessed: Jul.18, 2018.

MOLONY, V.; KENT, J.E. Sheep welfare: castration and tail docking. In: AITKEN, I. D. Diseases of Sheep. 4.ed. Edinburgh: Blackwell, 2007. Chap.4. p.27-32.

MORRIS, M.C. Ethical issues associated with sheep fly strike research, prevention, and control. Journal of Agricultural and Environmental Ethics, v.13, p.205-217, 2000. Available from: $<$ https://link.springer.com/article/10.1023/A:1009541810740>. Accessed: Jun. 04, 2018.

NATIONAL FARM ANIMAL CARE COUNCIL. Code of practice for the care and handling of sheep. Guelph: Canadian Sheep Federation, 2013. 104p.

ROBSON, C. Real world research: a resource for social scientists and practitioner-researchers. 2.ed. Oxford: Blackwell, 2002. 599p.

SEBRAE. Manual de boas práticas para ovinos de corte. 1.ed. São Paulo: SEBRAE, 2009. 66p.

SUTHERLAND, M.A.; TUCKER, C.B. The long and short of it: A review of tail docking in farm animals. Applied Animal Behaviour Science, v.135, n.3, p.179-191, 2011. Available from: <https:// www.sciencedirect.com/science/article/pii/S0168159111003200>. Accessed: Jun. 04, 2018. doi: 10.1016/j.applanim.2011.10.015.

TE VELDE, H. et al. Dealing with ambivalence: farmers' and consumers' perceptions of animal welfare in livestock breeding. Journal of Agricultural and Environmental Ethics, v.15, p.203219, 2002. Available from: <https://link.springer.com/article/10 $.1023 \% 2 F A \% 3 A 1015012403331$ ?LI=true >. Accessed: Nov. 18, 2018. doi: 10.1023/A:1015012403331. 